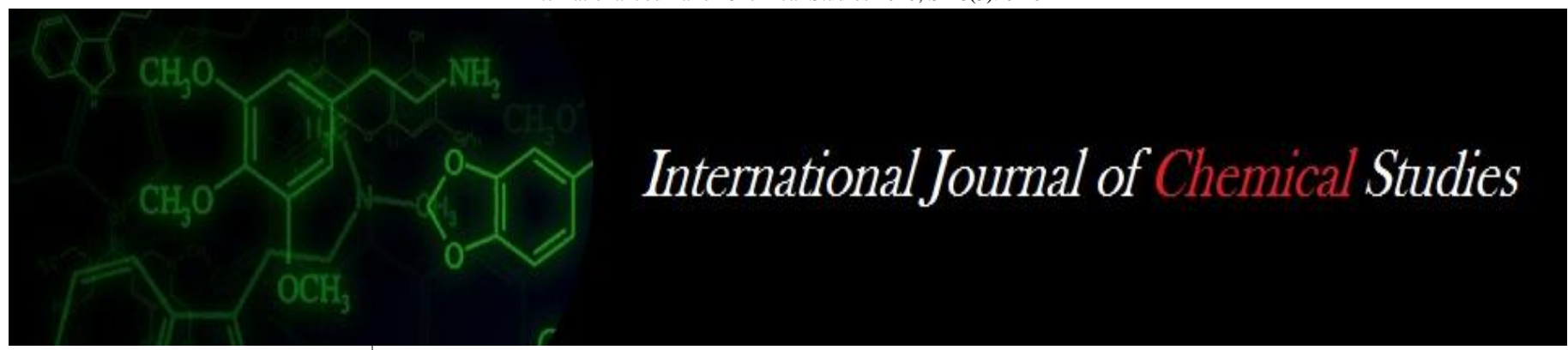

P-ISSN: 2349-8528

E-ISSN: 2321-4902

www.chemijournal.com

IJCS 2020; SP-8(5): 01-04

(C) 2020 IJCS

Received: 01-06-2020

Accepted: 03-08-2020

Nityamanjari Mishra

Regional Research and

Technology Transfer Station (OUAT), Keonjhar, Odisha,

India

\section{KC Sahoo}

Regional Research and

Technology Transfer Station

(OUAT), Keonjhar, Odisha,

India

\section{Ray}

Regional Research and

Technology Transfer Station

(OUAT), Keonjhar, Odisha,

India

\section{S Tudu}

Regional Research and

Technology Transfer Station (OUAT), Keonjhar, Odisha,

India

\section{A Mohapatra}

Krishi Vigyan Kendra (OUAT),

Keonjhar, Odisha, India
Corresponding Author: Nityamanjari Mishra

Regional Research and Technology Transfer Station (OUAT), Keonjhar, Odisha, India

\section{Performance of potato (Solanum tubersoum L.) genotypes during kharif season in Keonjhar district of Odisha, India}

\author{
Nityamanjari Mishra, KC Sahoo, M Ray, S Tudu and A Mohapatra
}

DOI: https://doi.org/10.22271/chemi.2020.v8.i5a.10332

\begin{abstract}
An experiment was conducted during kharif season in 2017. It was designed in randomized block design with three replications and 18 genotypes of potato (Solanum tuberosum L.) to identify the most suitable potato variety for Keonjhar agro-climatic condition during kharif season under rainfed conditions. Potato genotypes were evaluated for different growth parameters, yield attributes and yield characters. Among the vartieties tested, maximum number of tubers/ plant were recorded in variety Phulbani Local (32.0) which was statistically superior to rest other varieties. Phulbani Local recorded maximum tuber yield of 17.6 t/ha with B:C ratio of 2.2, which was statistically superior to all other varieties. Among big sized potato varieties, Kurfi Sinduri (13.90 t/ha, 1.7) and Kufri Surya (13.0 t/ha, 1.6) produced higher yield per hectare and B:C ratio respectively. However, the variety 2000P-55 (4.6 t/ha) resulted the lowest yield per ha which was at par with Kufri Himsona (4.9 t/ha) and Kufri Sailaja (5.3 t/ha) with negative B:C ratio. So, Variety Phulbani Local, Kufri Sinduri and Kufri Surya can be cultivated successfully during kharif season in Keonjhar Agro-climatic condition.
\end{abstract}

Keywords: Kharif, potato, yield, economics

\section{Introduction}

Potato (Solanum tubersoum L.) is one of the most important tuber crops in India. Food security is an important national priority in India. A short duration crop like potato produces more dry matter, edible energy and edible energy and protein per unit land and time. It is the most potential and nutritionally superior crop for fighting against hunger and malnutrition. So, It is also popularly known as "poor man's food". Apart from starch, it also provides essential body buildings substances such as high proteins, substantial amounts of essential vitamins and minerals (Horton and Sowyer, 1985 and Nikam et al., 2008) ${ }^{[1,3]}$.

India is the second largest potato producer in the world after China. Majority of potato in India (about $80 \%$ ) are grown in North western Indo-Gangetic plains during winter from October to February. About $10 \%$ are grown in Himalayas and Nilgiri hills during summer and only $7 \%$ in the warmer plateau region during rainy season as well as in winter season (Bairwa et al., 2016) [4]. In Odisha state of India, potato is cultivated in an area of 15,810 ha area with a production of 2.69 lakh tonnes, accordingly average productivity is only $17.02 \mathrm{t} / \mathrm{ha}$ which is far below the national average (Horticulture Statistics, 2016) ${ }^{[6]}$.

Being off season and fresh, the kharif potatoes possess better nutrition, texture and taste than the rabi season potatoes mainly grown in the plains of India. This advantage of kharif potatoes and meagre supply creates a strong demand for this produce. As an icing on the cake, kharif potato is harvested at a time when there is dearth of fresh potato in the country. So, this off season, kharif potato fetches 1.5 to 2 times higher prices compared to cold stored potato produced under rabi season in the plains (Rana et al. 2016) ${ }^{[5]}$. In India, Kharif potato crop is raised during June to September under rainfed conditions. Use of right varieties, good quality seed and recommended dose of fertilizers coupled with proper irrigation and phytosanitary measures will boost up the yield to feed the millions during off season (Nikam et al., 2008) ${ }^{[3]}$. The performance of any crop or variety largely depends on genotypic and environmental interactions. As a result, cultivars which perform well at one region may not show same performance in other region of varying climatic condition. Therefore, it is necessary to evaluate the available germplasm to find out the most promising genotypes suitable for 
cultivation for the particular Agro-climatic condition. Although, the yield of Rabi potato is more than Kharif potato but higher market price of Kharif potato as well as noninvolvement of irrigation cost relied on the lower total cost of production of Kharif potato.

However, very few research studies were carried out in Odisha exclusively on this aspect. It was therefore proposed to take up the present study viz., production of kharif potato in Keonjhar district of Odisha with an objective to assess the performance of different varieties of potatoes and to identify the most suitable potato variety for Keonjhar agro-climatic condition during kharif season.

\section{Materials and Methods}

The Keonjhar district is situated in northern part of Odisha and comes under North central plateaue zone which is located in the geographical parallels between $21^{\circ} 55^{\prime}$ North latitudes and $85^{\circ} 37^{\prime}$ East longitude. The climate of the zone is hot and sub-humid with mean maximum summer temperature of $35.2{ }^{\circ} \mathrm{C}$ (May) and mean minimum winter temperature of 13.3 ${ }^{\circ} \mathrm{C}$ (Dec-Jan). The night temperature of this area usually drops below $20^{\circ} \mathrm{C}$ during late kharif season which favours tuberization of the crop. The normal annual rainfall is 1331.2 $\mathrm{mm}$ of which about $87 \%$ is received during South West Monsoon season (June to September). Out of total rainfall, about $7 \%$ is received during Rabi (October to January) and about $6 \%$ during summer (February to May). Hence the area and the climate offer enough scope for kharif cultivation of potato. However, mean maximum temperature of $32{ }^{\circ} \mathrm{C}$ and mean minimum temperature of $15.5{ }^{\circ} \mathrm{C}$ with $646.9 \mathrm{~mm}$ of total rainfall was observed during cropping period (AugustNovember) in the year 2017 (Table -1). Soil of experimental plot was loamy in texture and slightly acidic with $\mathrm{pH} 6.5$ and EC $0.309 \mathrm{ds} / \mathrm{m}$, organic carbon $0.42 \%$, available $\mathrm{N}-106$ $\mathrm{kg} / \mathrm{ha}, \mathrm{P}_{2} \mathrm{O}_{5}-21.0 \mathrm{~kg} / \mathrm{ha}$ and $\mathrm{K}_{2} \mathrm{O}-225.0 \mathrm{Kg} / \mathrm{ha}$.

The 18 genotypes ( $\mathrm{V}_{1^{-}}$Kufri Lalit, $\mathrm{V}_{2}$-Kufri Garima, $\mathrm{V}_{3}$-Kufri Khyati, $\mathrm{V}_{4^{-}}$Kufri Lalima, $\mathrm{V}_{5^{-}} \mathrm{P}-7, \mathrm{~V}_{6^{-}}$Kufri Himsona, $\mathrm{V}_{7^{-}}$ 2000P-55, V- Kufri Surya, V $^{-} \quad$ P-14, V $10^{-}$Kufri Jyoti, $\mathrm{V}_{11^{-}}$MM-11, $\mathrm{V}_{12^{-}}$Kufri Pukhraj, $\mathrm{V}_{13^{-}}$Kufri Sailaja, $\mathrm{V}_{14^{-}}$ Kufri Sinduri, $\mathrm{V}_{15^{-}}$Kufri Gaurav, $\mathrm{V}_{16^{-}}$Kufri Ashoka, $\mathrm{V}_{17^{-}} \mathrm{P}-$ $12, \mathrm{~V}_{18^{-}}$Phulbani Local) used in the study included released varieties and local cultivars of potato belonging to Solanum tuberosum sub sp. tuberosum. These were evaluated during kharif season in 2017 at the experimental plot of RRTTS, Keonjhar. The trial was laid out in randomized block design (RBD) with three replications. Each variety in a replication was planted with a spacing of $20 \mathrm{~cm}$ (within row) and $60 \mathrm{~cm}$ between rows. Fertilization, weeding, cultural practices and need based plant protection measures were followed as recommended for kharif season cultivation. The observations for quantitative characters like shoots/plant, plant height $(\mathrm{cm})$ tuber number/plant, tuber weight/plant $(\mathrm{g})$ and total tuber yield ( $\mathrm{t} / \mathrm{ha}$ ) were recorded from five randomly selected plants from each replication and the data was statistically analyzed by applying the technique of analysis of variance (ANOVA) as described by Gomez and Gomez (1984). Mean values were calculated and compared using F-test at 5\% level of significance.

Table 1: Weather data during cropping period

\begin{tabular}{|c|c|c|c|c|c|c|}
\hline \multirow{2}{*}{ Month } & \multicolumn{2}{|c|}{ max. Temp. $\left(\mathbf{~}^{\mathbf{}} \mathbf{C}\right)$} & \multicolumn{2}{c|}{ min. Temp. $\left({ }^{\mathbf{}} \mathbf{C}\right)$} & \multicolumn{2}{c|}{ Rainfall (mm) } \\
\cline { 2 - 7 } & normal & $\mathbf{2 0 1 7}$ & normal & $\mathbf{2 0 1 7}$ & normal & $\mathbf{2 0 1 7}$ \\
\hline June & 33.4 & 34.5 & 23.8 & 24.8 & 208.6 & 234 \\
\hline July & 30.2 & 29.4 & 23.4 & 23.9 & 268.3 & 273.1 \\
\hline August & 30.0 & 31.1 & 22.9 & 24.0 & 273.1 & 296.1 \\
\hline September & 30.3 & 32.0 & 22.4 & 24.0 & 191.1 & 151 \\
\hline October & 30.0 & 30.7 & 19.7 & 21.4 & 103.4 & 183.9 \\
\hline November & 28.2 & 26.9 & 15.3 & 15.5 & 20.7 & 15.9 \\
\hline December & 26.0 & 26.1 & 11.4 & 11.4 & 9.9 & 0 \\
\hline
\end{tabular}

\section{Result and discussion}

All potato varieties cultivated during kharif season exhibited significant differences for different growth parameters like plant establishment, plant height $(\mathrm{cm})$ and number of shoots per plant. Percent of final plant stand per plot of the tubers varied significantly among genotypes (Table-2). Among all the cultivars, the plant establishment was found to be maximum in Phulbani Local (98.6\%) and was closely followed by Kufri Surya (93.1\%), Kufri Sinduri (90.3), Kufri Lalima (90.3), P-7 (88.9\%) and P-12 (88.9\%). However, the lowest plant stand was observed by Kufri Garima $(51.4 \%)$ in Kufri Himsona (56.9\%). Differences in the establishment of micro-plants among the potato cultivars can be attributed to the variable genetic base of the cultivars evaluated thus resulting in the differences in tissue hardiness as well as in the differences to tolerate stresses and transplanting shocks (Sharma et al., 2013) ${ }^{[10]}$.

Maximum number of shoots/plant were observed in Phulbani Local (10.2) which is statistically superior to rest other varieties. Whereas the lowest number of shoots per plant was found in Kufri Khyati (1.7) which was statistically at par with Kufri Himsona (1.8) and 2000P-55 (2.1). The reason for less numbers of shoots per plant in Kufri Khyati, Kufri Himsona and 2000P-55 might be due to poor germination vis-à-vis plant establishment leading to lower shoots per plants.

The variety Phulbani Local recorded the tallest plants with values $31.01 \mathrm{~cm}$ which was also statistically superior to rest other varieties. However, the lowest plant height was recorded in variety Kufri Jyoti $(13.85 \mathrm{~cm})$ which was statistically at par with 2000P-55 (14.36 cm), Kufri Gaurav (14.14 cm).

Number of tubers per plant and weight of tubers per plant are considered as two most important yield attributing characters for determining the yield of the crop. The maximum number of tubers/ plant were recorded in variety Phulbani Local (32.0) which was statistically superior to rest other varieties because variety Phulbani Local is a baby potato variety which produces more numbers of small sized baby potatoes. Among big sized potato varieties Kufri Surya produces the highest number of tubers (11.1) followed by Kufri Sinduri (9.0) and P-14 (8.1). However, minimum numbers of tubers/plant were observed in variety Kufri Jyoti (4.4) followed by variety 2000P-55(4.8) and Kufri Sailaja (4.9). The varieties which recorded higher values for other growth parameters like plant height and number of shoots per plant resulted more numbers of tubers/plant (Pandey et al. 2005, Maharana et al., 2017) ${ }^{[8,}$ 9]. 
The genotype Phulbani Local registered maximum weight of the tuber per plant (176.11g) followed by Kufri Sinduri $(166.44 \mathrm{~g})$ and Kufri Surya (156.22g). However, the minimum tuber weight/plant was recorded in variety $2000 \mathrm{P}-$ $55(45.98 \mathrm{~g})$. Phulbani Local recorded maximum tuber yield of $17.6 \mathrm{t} / \mathrm{ha}$ which was statistically superior to all other varieties. Among big sized potato varieties, Kufri Sinduri (13.90 t/ha) and Kufri Surya (13.0 t/ha) produced higher yield per hectare. However, the variety 2000P-55 (4.6 t/ha) resulted the lowest yield per ha which was at par with Kufri Himsona (4.9 t/ha) and Kufri Sailaja (5.3 t/ha). As the crop was raised in offseason (Kharif), the heavy rainfall during the growth stage of the crop affected the final plant stand of the plot so the obtained yield was on lower side (Maharana et al., 2017) ${ }^{[9]}$.
Higher gross return was noticed in potato variety Phulbani Local (Rs. 264165/ha) followed by Kufri Sinduri (Rs. 207957/ ha) and Kufri Surya (Rs. 195383/ha). The highest net return and Hight B:C ratio was also realized with variety Phulbani Local (Rs. 145235 and 2.2) followed by Kufri Sinduri (Rs. 89027 and 1.7) and Kufri Surya (Rs.76453 and 1.6) respectively. However, the varieties Kufri Lalit, Kufri Garima, Kufri Kyati, Kufri Himsona, 2000P-55, Kufri Jyoti, Kufri Sailaja, Kufri Ashoka gave negative return and are not economically viable for cultivation during Kharif season in Keonjhar Agro- climatic condition. However, among all variety Kufri Himsona (0.6) and 2000P-55 (0.6) resulted the lowest B:C ratio followed by Kufri Sailaja (0.7).

Table 2: Growth and yield attributes of Potato genotypes during kharif season

\begin{tabular}{|c|c|c|c|c|c|c|}
\hline \multicolumn{2}{|c|}{ Treatments } & Final plant stand & Plant height (cm) & No. of shoots /plant & No. of tuber /plant & Weight of tuber (g)/plant \\
\hline $\mathrm{V}_{1}$ & K. Lalit & 63.9 & 2.7 & 2.7 & 5.1 & 95.53 \\
\hline $\mathrm{V}_{2}$ & K. Garima & 51.4 & 3.4 & 3.4 & 5.9 & 98.44 \\
\hline $\mathrm{V}_{3}$ & K. Khyati & 79.2 & 1.7 & 1.7 & 5.4 & 84.89 \\
\hline $\mathrm{V}_{4}$ & K. Lalima & 90.3 & 3.5 & 3.5 & 5.0 & 132.53 \\
\hline $\mathrm{V}_{5}$ & P-7 & 88.9 & 4.6 & 4.6 & 5.9 & 130.55 \\
\hline $\mathrm{V}_{6}$ & K. Himsona & 56.9 & 1.8 & 1.8 & 6.8 & 70.67 \\
\hline $\mathrm{V}_{7}$ & 2000P-55 & 63.9 & 2.1 & 2.1 & 4.8 & 45.98 \\
\hline $\mathrm{V}_{8}$ & K. Surya & 93.1 & 3.9 & 3.9 & 11.1 & 156.22 \\
\hline $\mathrm{V}_{9}$ & P-14 & 79.2 & 5.1 & 5.1 & 8.1 & 139.66 \\
\hline $\mathrm{V}_{10}$ & K. Jyoti & 83.3 & 2.8 & 2.8 & 4.4 & 75.78 \\
\hline $\mathrm{V}_{11}$ & MM-11 & 76.4 & 3.6 & 3.6 & 6.0 & 146.43 \\
\hline $\mathrm{V}_{12}$ & K. Pukhraj & 70.8 & 4.1 & 4.1 & 7.2 & 154.33 \\
\hline $\mathrm{V}_{13}$ & K. Sailaja & 70.8 & 2.8 & 2.8 & 4.9 & 74.62 \\
\hline $\mathrm{V}_{14}$ & K. Sinduri & 90.3 & 3.6 & 3.6 & 9.0 & 166.44 \\
\hline $\mathrm{V}_{15}$ & K. Gaurav & 84.7 & 4.0 & 4.0 & 6.6 & 127.66 \\
\hline $\mathrm{V}_{16}$ & K. Ashoka & 76.4 & 3.9 & 3.9 & 6.0 & 82.67 \\
\hline $\mathrm{V}_{17}$ & P-12 & 88.9 & 5.4 & 5.4 & 7.2 & 107.00 \\
\hline $\mathrm{V}_{18}$ & Phulbani Local & 98.6 & 10.2 & 10.2 & 32.0 & 176.11 \\
\hline \multicolumn{2}{|c|}{ Sem $( \pm)$} & 3.86 & 0.71 & 0.21 & 0.71 & 2.77 \\
\hline \multicolumn{2}{|l|}{ CD $(0.05)$} & 11.08 & 2.03 & 0.61 & 2.03 & 7.96 \\
\hline
\end{tabular}

Table 3: yield and economics of Potato genotypes during kharif season

\begin{tabular}{|c|c|c|c|c|c|c|}
\hline \multicolumn{2}{|r|}{ Treatments } & \multirow{2}{*}{$\begin{array}{c}\text { Plot yield (kg) } \\
1.78\end{array}$} & \multirow{2}{*}{$\frac{\text { Yield (t/ha) }}{7.4}$} & \multirow{2}{*}{$\begin{array}{c}\text { Gross income (Rs) } \\
111404\end{array}$} & \multirow{2}{*}{$\begin{array}{c}\text { Net Return (Rs) } \\
-7526\end{array}$} & \multirow{2}{*}{$\frac{B: C}{0.9}$} \\
\hline $\mathrm{V}_{1}$ & K. Lalit & & & & & \\
\hline $\mathrm{V}_{2}$ & K. Garima & 1.48 & 6.2 & 92519 & -26411 & 0.8 \\
\hline $\mathrm{V}_{3}$ & K. Khyati & 1.72 & 7.2 & 107775 & -11155 & 0.9 \\
\hline $\mathrm{V}_{4}$ & K. Lalima & 2.87 & 12.0 & 179574 & 60644 & 1.5 \\
\hline $\mathrm{V}_{5}$ & P-7 & 2.78 & 11.6 & 173566 & 54636 & 1.5 \\
\hline $\mathrm{V}_{6}$ & K. Himsona & 1.19 & 4.9 & 74104 & -44826 & 0.6 \\
\hline $\mathrm{V}_{7}$ & $2000 \mathrm{P}-55$ & 1.10 & 4.6 & 68449 & -50481 & 0.6 \\
\hline $\mathrm{V}_{8}$ & K. Surya & 3.13 & 13.0 & 195383 & 76453 & 1.6 \\
\hline $\mathrm{V}_{9}$ & P-14 & 2.84 & 11.8 & 177258 & 58328 & 1.5 \\
\hline $\mathrm{V}_{10}$ & K. Jyoti & 1.74 & 7.3 & 109040 & -9890 & 0.9 \\
\hline $\mathrm{V}_{11}$ & MM-11 & 2.87 & 12.0 & 179660 & 60730 & 1.5 \\
\hline $\mathrm{V}_{12}$ & K. Pukhraj & 2.62 & 10.9 & 163823 & 44893 & 1.4 \\
\hline $\mathrm{V}_{13}$ & K. Sailaja & 1.27 & 5.3 & 79219 & -39711 & 0.7 \\
\hline $\mathrm{V}_{14}$ & K. Sinduri & 3.33 & 13.9 & 207957 & 89027 & 1.7 \\
\hline $\mathrm{V}_{15}$ & K. Gaurav & 2.60 & 10.8 & 162295 & 43365 & 1.4 \\
\hline $\mathrm{V}_{16}$ & K. Ashoka & 1.51 & 6.3 & 94521 & -24409 & 0.8 \\
\hline $\mathrm{V}_{17}$ & $\mathrm{P}-12$ & 2.28 & 9.5 & 142778 & 23848 & 1.2 \\
\hline $\mathrm{V}_{18}$ & Phulbani Local & 4.23 & 17.6 & 264165 & 145235 & 2.2 \\
\hline & $\operatorname{Sem}( \pm)$ & & 0.11 & 0.46 & & \\
\hline & $\mathrm{CD}(0.05)$ & & 0.32 & 1.32 & & \\
\hline
\end{tabular}

\section{Conclusion:}

From the results, it can be concluded that potato cultivation can become a boon for the regions having such climatic advantages during Kharif season. Potato production can be taken up successfully during Kharif season in Keonjhar Agroclimatic condition. Although, the yield of Rabi potato is more than Kharif potato but higher market price of Kharif potato as well as non-involvement of irrigation cost relied on the lower total cost of production of Kharif potato (Rana et al., 2016) ${ }^{[5]}$. Choosing the right variety along with with proper cultural practice is the most important thing which should be taken care of for kharif Potato cultivation. 
However, potato variety Phulbani Local, Kufri Sinduri and Kufri Surya can be cultivated successfully during kharif season in Keonjhar agroclimatic condition.

\section{References}

1. Horton D, Sawyer RL. The potato as a world food crop, with special reference to developing areas. In: P.H. Li (Ed.), Potato physiology. Academic Press, London, 1985, 1-34.

2. Nag D, Roy P, Dutta AK. Seasonal potato cultivation in Ranchi district- a comparative study, Human Resource Reflection, 2015; 2(4):35-40.

3. Nikam AV, Shendage PN, Jadhav KL, Deokate TB. Economics of production of kharif potato in Satara, India, Internat. J. Agric. Sci., 2008; 4(1):274-279.

4. Bairwa A, Venkatasalam EP, Sudha R, Umamaheswari R, Sharma S, Singh BP. Management of Late blight disease in Kharif potato at Karnataka. Potato Journal, 2016; 43(2):173-181.

5. Rana RK, Kumar Sanjay, Chaudhary KR. Kharif Potato Production in India, Indian Farming, 2016; 66(4):13-15.

6. Horticultural Statistics at a Glance. Horticulture Statistics Division, Department of Agriculture, Cooperation, Ministry of Agriculture and Farmers Welfare, Government of India, 2016.

7. Gomez KA, Gomez AA. Statistical procedures for agricultural research. John Wiley \& Sons, New York., USA, 1984

8. Pandey SK, Singh SV, Manivel P. Yield structure, agronomic performance and stability of new potato (Solanum tuberosum) hybrids in western Uttar Pradesh. Indian J. Agricultural Sciences. 2005; 75(7):417-421.

9. Maharana J, Panda CM, Jakhar P. Genetic variability among genotypes and character association in kharif potato (Solanum tuberosum L.) for different traits. The Bioscan, 2017; 2(2):1195-1202.

10. Sharma AK, Venkatasalam EP, Kumar V. Potato minituber Production during main and off crop seasons in high hills of North-Western Himalaya, Potato Journal. 2013; 40(1):29-37 